\title{
Perbedaan Kemampuan Membaca Pemahaman Siswa pada Model Pembelajaran PQ4R Mata Pelajaran Bahasa Indonesia
}

\author{
Amin Mustajab ${ }^{1}$, Yulia Deodata Selestin ${ }^{2}$, Puji Rahmawati ${ }^{3}$, Agustina Fini Widya $^{4}$ \\ ${ }^{1,2,3,4}$ STKIP Melawi \\ Email: aminmustajab53@gmail.com
}

\begin{abstract}
Abstrak
Penelitian ini dilatar belakangi oleh temuan peneliti yang menunjukan bahwa rerata kemampuan membaca pemahan siswa masih rendah pada model pembelajaran konvensional. Peneliti mengganti model pembelajaran konvensional yang diterapkan selama ini dengan model pembelajaran PQ4R (Preview, Question, Read, Recite, Review, dan Reflect). PQ4R adalah merupakan rangkaian inovasi dari pendekatan konstruktivis dalam belajar yang mendorong siswa untuk mengeksplorasi kemampuannya membuat struktur berpikir sebelum membaca dengan menyusun pertanyaan-pertanyaan yang menjadi acuan bagi siswa untuk menggali informasi yang dibutuhkan dari teks bacaan. Tujuan dari penelitian ini untuk melihat apakah terdapat perbedaan kemampuan membaca pemahaman siswa sebelum dan sesudah mengikuti pembelajaran menggunakan model PQ4R. Penelitian ini merupakan penelitian kuantitatif menggunakan desain penelitian one-group pretest-posttest. Instrmen yang digunakan berupa tes tertulis sebanyak 6 (enam) soal esai yang terdiri dari indikator menyebutkan tokoh uatama dalam karangan, menjelaskan makna dari kata, menentukan ide utama dari paragraf, menjelaskan amanat dari karangan, serta membuat ringkasan dari karangan. Temuan penelitian ini terdapat perbedaan tingkat kemapuan membaca pemahaman siswa sebelum dan setelah mengikuti pembelajaran menggunakan model PQ4R. Setelah mengikuti pembelajaran menggunakan model PQ4R terjadi penigkatan sebesar 9\% kemampuan membaca pemahaman siswa pada kategori baik dan terjadi peningkatan sebesar $5 \%$ pada kategori sangat baik.
\end{abstract}

Kata kunci: Bahasa Indonesia, Kemampuan membaca pemahan, Model Pembelajaran PQ4R

\section{Abstract}

This research is motivated by the findings of researchers which show that the average reading comprehension ability of students is still low in conventional learning models. The researcher replaced the conventional learning model that has been applied so far with the PQ4R learning model (Preview, Question, Read, Recite, Review, and Reflect). $P Q 4 R$ is a series of innovations from a constructivist approach to learning that encourages students to explore their ability to structure thinking before reading by compiling questions that become references for students to extract the information needed from the reading text. The purpose of this study was to see if there were differences in students' reading comprehension skills before and after learning using the PQ4R model. This research is a quantitative study using a one-group pretest-posttest research design. The instrument used is a written test of 6 (six) essay questions consisting of indicators mentioning main characters in the essay, explaining the meaning of the word, determining the main idea of the paragraph, explaining the message of the essay, and making a summary of the essay. The findings of this study are there are differences in the level of reading comprehension of students before and after participating in learning using the PQ4R model. After participating in learning using the PQ4R model, there was an increase of $9 \%$ in the students' reading comprehension ability in the nifty level and an increase of $5 \%$ in the very nailing.

Keywords: Indonesian, PQ4R Learning Model, Reading comprehension skills

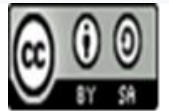

Received: November 19, 2020 Revised: March 30, 2021 Accepted: Mrch 31, 2021 


\section{Pendahuluan}

Membaca merupakan salah satu keterampilan berbahasa selain menyimak, berbicara, dan menulis. Dengan membaca kita akan berpengetahuan luas mengenai ilmu pengetahuan, teknologi, sosial maupun bidang ilmu lainnya. Kemampuan membaca merupakan sesuatu yang sangat penting dalam suatu masyarakat terpelajar. Belajar membaca merupakan usaha terus menerus. Pembelajaran membaca mempunyai kedudukan yang strategis dalam pendidikan dan pengajaran (Boliti, 2013). Kegiatan membaca juga dapat membantu kita dalam memahami kejadian atau maksud dari sebuah tulisan. Proses memahami maksud sebuah tulisan bisa dikatakan sebagai kegiatan membaca pemahaman. Menurut Tusfiana (Tusfiana \& Trynasari, 2020)kemampuan yang dimiliki seseorang dalam mengkontruksi pesan yang terdapat dalam isi bacaan dengan menghubungkan pengetahuan dengan ide pokok serta inti dari bacaan yang dibaca. Membaca pemahaman dapat pula diartikan sebagai proses sebagai proses sungguhsungguh yang dilakukan pembaca untuk memperoleh informasi, pesan, dan makna yang terkandung dalam sebuah bacaan (Nindy Rahayu, 2017). Dapat disimpulkan bahwa membaca pemahaman adalah kegiatan membaca bacaan secara teliti dan seksama dengan tujuan memahaminya secara rinci baik yang tersurat maupun yang tersirat dari bahan bacaan tersebut untuk mencapai hasil yang optimal dalam pembelajaran.

Temuan dari Somadayo (Somadayo, 2016) siswa masih mengalami hambatan dalam proses membaca, hambatan-hambatan tersebut adalah siswa kurang mampu: (1) mengidentifikasi tema, topik, atau judul wacana, (2) menilai organisasi wacana tentang ide pokok, ide penjelas, kalimat topik, kalimat penjelas, dan jenis alinea, (3) menemukan informasi berupa fakta, definisi, atau konsep, (4) Mampu memahami makna kata, istilah, dan ungkapan, dan (5) menarik simpulan tentang hal, konsep, masalah, atau pendapat. Selain itu menurut Slamet (Slamet, 2009) permasalahan rendahnya kualitas kemampuan membaca ini disebabkan oleh beberapa hal, di antaranya (1) penekanan bahan pelajaran yang lebih teoretis, (2) kurang kegiatan praktis dalam membina dan meningkatkan kemampuan membaca pemahaman, (3) pemilihan dan penerangan strategi/pendekatan yang kurang tepat, (4) kondisi bahan pengajaran yang kurang memadai, (5) rendahnya kemampuan membaca pemahaman mahasiswa disebabkan oleh penguasaan struktur dan penguasaan derivasi. Untuk itu diperlukan upaya untuk mengatasi kesulitan-kesulitan tersebut, salah satu upaya untuk mentasi hal tersebut adalah menggunakan model pembelajaran yang dapat membatu siswa memahami isi bacaan.

Menurut Rikmasari dan Lestari (Rikmasari \& Lestari, 2018) menjelaskan bahwa strategi Preview, Question, Read, Reflect, Recite, and Review (PQ4R) merupakan rangkaian inovasi dari pendekatan konstruktivis dalam belajar. Langkah-langkah ini dapat membantu siswa menguasai atau lebih memahami informasi. Siswa diminta untuk mengeksplorasi kemampuannya membuat struktur berpikir sebelum membaca dengan menyusun pertanyaan-pertanyaan yang menjadi acuan bagi siswa untuk menggali informasi yang dibutuhkan dari teks bacaan (Tetu, Simpen, \& Sutama, 2019). Menurut Yuliana dan Fajriah (Yuliana \& Fajriah, 2013) langkah-langkah yang harus dilakukan dalam strategi PQ4R adalah sebagai berikut:(1) Preview, membaca dengan selintas topik utama, membaca tinjauan umum, rangkuman, dan meramalkan bacaan tersebut akan membahas apa, (2) Question, mendalami dan mengajukan pertanyaan yang jawabannya dapat ditemukan dalam bacaan tersebut, (3) Read, membaca bahan tersebut, memberikan perhatian pada ide-ide utama dan carilah jawaban atas pertanyaan yang diajukan tadi, (4) Reflect, refleksi sambil membaca, cobalah untuk menghubungkan informasi dari bacaan dengan apa yang diketahui, (5) Recite, setelah membaca, lakukan resitasi yaitu menjawab dengan suara keras pertanyaan-pertanyaan yang diajukan tanpa membuka buku. Hapalkan fakta-fakta penting lainnya yang terdapat dalam bacaan dengan suara keras atau suara pelan, dan (6) Review, mengulang kembali seluruh bacaan, baca ulang bila perlu, dan jawab kembali pertanyaan yang diajukan, kemudian tentukan intisari dari bacaan. 


\section{Metode Penelitian}

Penelitian ini menggunakan metode kuantitatif, jenis penilitian yang digunakan eksperimen dengan model One Grup Pretest Postest. Penelitian ini dilakukan pada SD Negeri 03 Sontas tahun 2019. SD Negeri 03 Sontas terletak di Kabupaten Sanggau, Kalimantan Barat, berbatasn langsung dengan Negara Malaysia. Jumlah sampel sebanyak 22 siswa terdiri dari 8 laki-laki dan 14 perempuan. Data dalam penelitian ini diperoleh dari hasil tes tertulis. Instrumen yang digunakan dalam penelitian ini berupa tes untuk mengukur kemampuan membaca pemahaman siswa kelas yang terdiri dari 6 soal essay. Indikator soal terdiri dari mampu menyebutkan tokoh utama dalam karangan, mampu menjelaskan makna dari kata, mampu menentukan ide utama dari paragraf, mampu menjelaskan amanat dari karangan, serta mampu membuat ringkasan dari karangan. Untuk mengkategorikan kemampuan membaca pemahaman siswa diukur menggunakan indikator kemampuan membaca pemahaman dapat dilihat pada Tabel 1.

Validitas instrumen menggunakan uji validitas isi yang dilakukan oleh dua orang tenaga ahli. Untuk menguji normal atau tidaknya dilakukan dengan menggunakan uji Shapiro Wilk. Untuk menguji homogenitas data pre-test dan post-test dilakukan dengan menggunakan uji Fisher. Untuk mengetahui ada tidaknya perbedaan secara statistik diperoleh dari data pre-test dan data post-test yang diuji menggunakan uji Wlicoxon. Uji Wilcoxon dipilih karena distribusi data post-tes tidak normal. Uji Wilcoxon dilakukan menggunakan aplikasi SPSS-22 guna mempermudah perhitungan. Penarikan kesimpulan uji Wilcoxon menggunakan SPSS-22 dengan membandingkan nialai Asymp. Sig. (2-tailed) terhadap nilai signifikasi 0,05, apabila nilai Asymp. Sig. (2-tailed) lebih kecil dari nilai signifikasi maka dapat ditarik kesimpulan bahwa terdapat perbedaan secara statistik kemampuan membaca pemahaman siswa sebelum dan sesudah mengikuti pembelajaran menggunakan model PQ4R. Berikut ini adalah kriteria untuk menginterpretasi kemampuan membaca pemahaman.

Tabel 1. Indikator Kemampuan Membaca Pemahaman

\begin{tabular}{ccc}
\hline No & $\begin{array}{c}\text { Tingkat Kemampuan } \\
\text { Membaca Pemahaman }\end{array}$ & Nilai \\
\hline 1 & Buruk sekali & $0-20$ \\
\hline 2 & Buruk & $21-40$ \\
\hline 3 & Sedang & $41-60$ \\
\hline 4 & Baik & $61-80$ \\
\hline 5 & Baik Sekali & $81-100$ \\
\hline Sumber: Mustofa \& Rusdiana (Mustofa \& Rusdiana, 2016) dimodifikasi.
\end{tabular}

\section{Hasil dan Pembahasan}

\section{Hasil Penelitian}

Hasil validitas isi yang dinilai oleh 2 orang ahli diperoleh nilai rerata 5 dengan kategori sangat baik. Hasil ini menunjukan bahwa instrumen penelitian yang digunakan dalam penelitia ini dapat digunakan tanpa revisi. Hasil uji normalitas pada data pre-test dan post-test dilakukan menggunakan uji Shapiro Wilk. Hasil perhitungan menggunakan uji Shapiro Wilk untuk data pre-test diperoleh data 0,088 >0,05 sehingga dapat disimpulkan data pre-test berdistribusi norma. Sedangkan untuk data pos-test signifikansi Shapiro Wilknya 0,048 $<0,05$ dapat disimpulkan bahwa data post-test tidak berdistribusi normal. 
Amin Mustajab, Yulia Deodata Selestin, Puji Rahmawati, Agustina Fini Widya Perbedaan Kemampuan Membaca Pemahaman Siswa pada Model Pembelajaran PQ4R

Mata Pelajaran Bahasa Indonesia

Tabel 2. Hasil Uji Normalitas Shapiro-Wilk Menggunakan SPSS

\begin{tabular}{lcccccc}
\hline \multicolumn{6}{c}{ Test of Normality } \\
\hline & \multicolumn{2}{c}{ Kolmogorov-Smirnov ${ }^{\text {a }}$} & \multicolumn{3}{c}{ Shapiro-Wilk } \\
\cline { 2 - 7 } & Statistic & df & Sig. & $\begin{array}{c}\text { Statisti } \\
\text { c }\end{array}$ & df & Sig. \\
\hline Prete & .145 & 22 & $.200^{*}$ & .923 & 22 & .088
\end{tabular}

Hasil uji Wilcoxon menggunakan SPSS dapat dilihat pada Tabel 3. Berdasarkan uji Wilcoxon menggunakan SPSS pada Tabel 3. dapat disimpulkan bahwa terdapat perbedaan secara statistik kemampuan membaca pemahaman siswa sebelum dan sesudah mengikuti pembelajaran menggunakan model PQ4R. Hal ini menunjukan terjadinya peningkatan kemampuan membaca pemahaman siswa setelah mengikuti pembelajaran melalui model PQ4R pada kategori baik dan sangat baik (dapat dilihat pada Gambar 3.).

Tabel 3. Hasil Uji Wilcoxon Menggunakan SPSS

\begin{tabular}{cc}
\hline \multicolumn{2}{c}{ Test Statistics $^{\mathrm{a}}$} \\
\hline Posttest - Pretest $^{-}$ \\
\hline $\mathrm{Z}$ & $-3.663^{\mathrm{b}}$ \\
\hline Asymp. Sig. (2-tailed) & .000 \\
\hline
\end{tabular}

a. Wilcoxon Signed Ranks Test

b. Based on negative ranks.

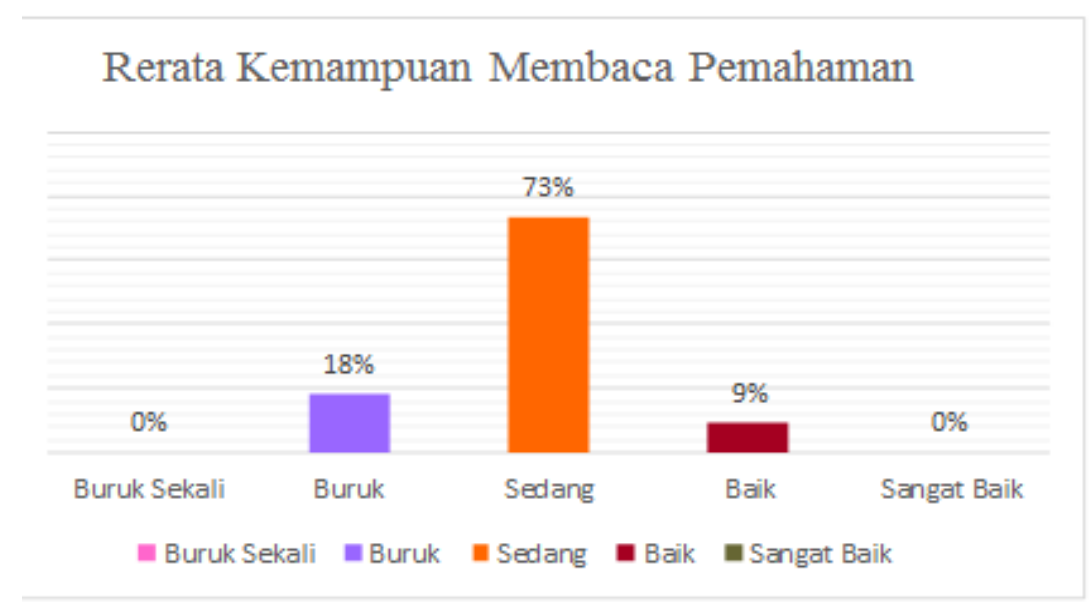

Gambar 1. Rerata kemampuan membaca pemahaman pada pre-test.

Rerata kemampuan membaca pemahan siswa sebelum mengikuti pembelajaran menggunakan model PQ4R dapat dilihat pada Gambar 1. Tidak terdapat siswa yang memiliki kemampuan membaca pemahaman pada ketegori buruk sekali. Terdapat $18 \%$ siswa pada ketegori buruk. Pada kategori sedang kemampuan membaca pemahaman sebanyak $73 \%$ siswa. 9\% siswa pada kategori baik dan tidak terdapat siswa yang memiliki kemampuan membaca pemahaman pada kategori sangat baik. 


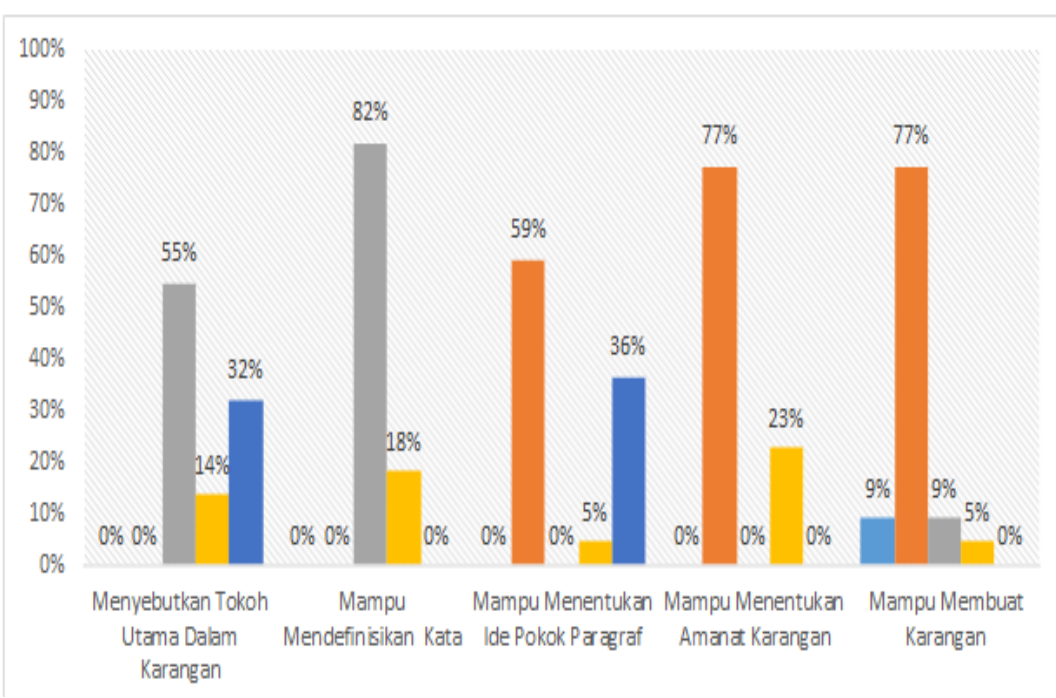

Gambar 2. Rerata kemampuan membaca pemahaman tiap indikator pada pre-test

Rerata kemampuan membaca pemahaman siswa sebelum mengikuti pembelajaran menggunakan model PQ4R pada tiap indikator dapat dilihat pada Gambar 2. Pada indikator kemampuan menyebutkan tokoh utama dalam karangan tidak terdapat siswa pada kategori buruk dan buruk sekali. Sebanyak 55\% siswa berada pada kategori sedang. Pada kategori baik tedapat $14 \%$ siswa dan pada kategori baik sekali $32 \%$. Pada indikator mampu mendefinisikan kata tidak terdapat siswa pada kategori buruk sekali, buruk dan baik sekali.

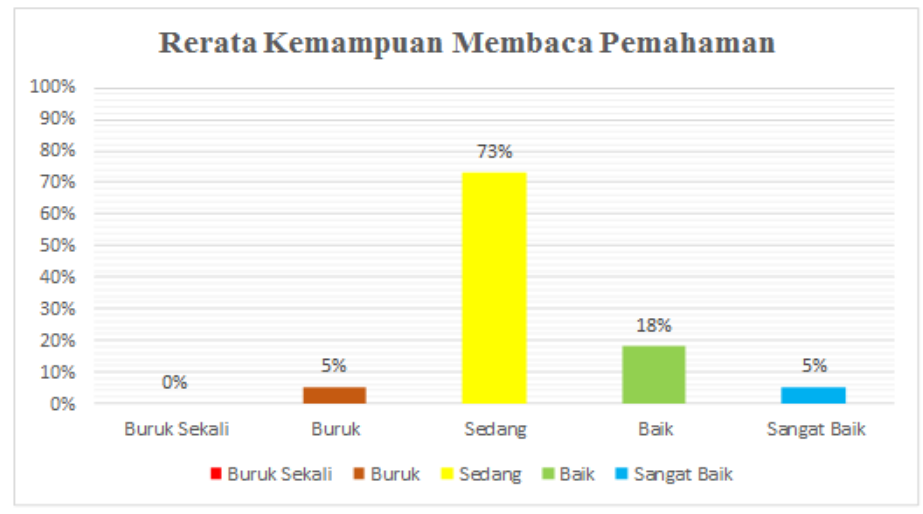

Gambar 3. Rerata kemampuan membaca pemahaman pada post-test.

Sebanyak $82 \%$ siswa berada pada kategori sedang dan $18 \%$ siswa berada pada kategori baik. Pada indikator mampu menentukan ide pokok paragraf tidak terdapat siswa pada kategori buruk sekali dan sedang. Pada kategori buruk terdapat 59\%. Sebanyak 5\% pada kategori baik dan 36\% pada kategori baik sekali. Pada indikator mampu menentukan amanat karangan tidak terdapat siswa dengan kategori buruk, sedang dan baik sekali. Terdapat $77 \%$ siswa dengan kategori buruk dan 23\% siswa berada pada kategori baik. Pada indikator membuat ringkasan tidak terdapat siswa pada kategori baik sekali. Pada kategori buruk sekali sebanyak $9 \%$ siswa, sebanyak 77\% siswa pada kategori buruk, pada kategori sedang sebanyak 9\% dan 5\% siswa berada pada kategori baik.

Rerata kemampuan membaca pemahaman siswa sebelum mengikuti pembelajaran menggunakan model PQ4R dapat dilihat pada Gambar 3. Tidak terdapat siswa yang memiliki 
kemampuan membaca pemahaman pada kategori buruk. Pada kategori buruk terdapat sebanyak $5 \%$. Pada kategori sedang sebanyak $73 \%, 18 \%$ pada kategori baik dan $5 \%$ pada kategori baik sekali.

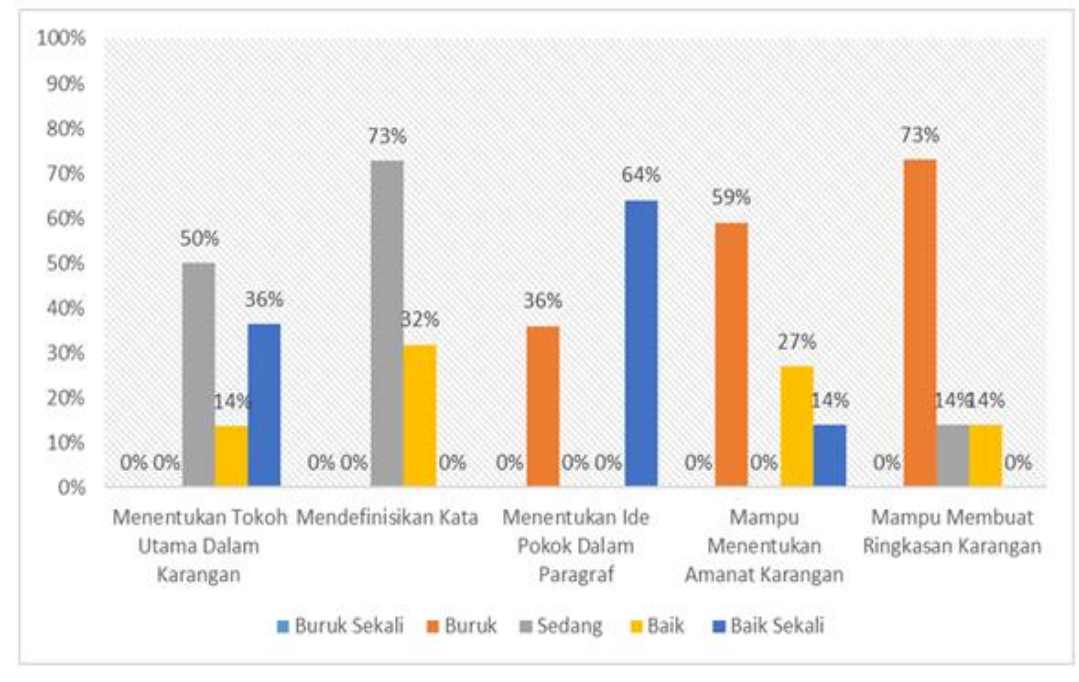

\section{Gambar 4. Rerata kemampuan membaca pemahaman tiap indikator pada post-test.}

Rerata kemampuan membaca pemahaman siswa tiap indikator setalah mengikuti pembelajaran menggunakan model PQ4R dapat dilihat pada Gambar 4. Pada indikator mampu menentukan tokoh utama dalam karangan tidak terdapat siswa pada kategori buruk sekali dan buruk. Pada kategori sedang terdapat 50\%, sebanyak 14\% pada kategori baik dan $36 \%$ berada pada ketegori baik sekalli. Pada indikator mendefinisikan kata tidak terdapat siswa pada kategori buruk sekali, buruk dan baik sekali. Sebanyak 73\% siswa berada pada kategori sedang dan 32\% siswa berada kategori baik. Pada indikator menentukan ide pokok dalam paragraf tidak terdapat siswa pada kategori buruk sekali, sedang dan baik. Terdapat $36 \%$ siswa berada pada kategori buruk dan $64 \%$ berada pada ketegori baik sekali. Pada indikator mampu menentukan amanat karangan tidak terdapat siswa pada ketegori buruk sekali dann sedang. Pada ketegori buruk terdapat 59\% siswa, 27\% berada pada ketegori baik dan 14\% berada pada kategori baik sekali. Pada indikator mampu membuat ringasan karangan tidak terdapat siswa pada ketegori buruk sekali dan baik sekali. Terdapat 73\% siswa berada pada kategori buruk, 14\% siswa berada pada kategori sedang dan $14 \%$ berada pada kategori baik.

\section{Pembahasan}

Hasil uji statistik menggunakan uji Wilcoxon menunjukan bahwa terdapat perbedaaan secara statistik kemampuan membaca pemahaman sebelum dan setelah mengikuti pembelajaran menggunakan model PQ4R. Hal ini dapat dilihat pada Gamabar 3. terjadi peningkatan kemampuan membaca pemahaman siswa pada kategori baik dan baik sekali setelah mengikuti pembelajaran menggunakan model PQ4R. Temuan ini sejalan dengan Wangka (Wangka \& Usman, 2017) yang menunjukan ada peningkatan hasil belajar siswa setelah mengikuti pembelajaran menggunakan model PQ4R, namun di lain pihak, setelah mengikuti pembelajaran menggunakan model PQ4R terjadi penurunan kemampuan membaca pemahaman siswa pada kategori buruk. Hal ini sejalan dengan temuan Sartika (Sartika \& Effendi, 2019) terdapat pengaruh model pembelajaran PQ4R terhadap kemampuan menganalisis naskah drama.

Perbedaan kemampuan membaca pemahaman sebelum dan setelah mengikuti pembelajaran menggunakan model $\mathrm{PQ} 4 \mathrm{R}$ ini terjadi karena dalam pembelajaran PQ4R ini 
menekankan siswa untuk menemukan sendiri materi yang dapat digali melalui kegiatan membaca yang dilakukan secara aktif dan sistematis (Pramana, Lasmawan, \& Istri Ngurah Marhaeni, 2014). Selain itu perbedaan ini terjadi dikarenakan beberapa hal; Pertama, terjadi peningkatan kemampuan membaca pemahaman pada inidikator dapat menentukan tokoh utama dalam karangan sebesar 2\% dikategori baik sekali. Model pembelajaran PQ4R memberikan kesempatan kepada siswa agar lebih memahami bacaan melalui langkah question. Pada langkah ini siswa diminta membuat pertanyaan apa, mengapa, siapa dan bagaimana (Nasution, 2018). Dengan mengajukan pertanyaan, siswa akan lebih memahami bacaan sehingga siswa lebih mudah dalam mengetahui tokoh didalam karangan. Hal ini sejalan dengan pendapat Linayaningsih pengalaman telah menunjukkan bahwa apabila seseorang membaca untuk menjawab sejumlah pertanyaan, maka akan membuat dia membaca lebih hatihati serta seksama serta akan dapat membantu mengingat apa yang dibaca dengan baik

Kedua, pada indikator dapat mendefinisikan kata pada karangan terjadi peningkatan sebesar $14 \%$ di kategori baik. Hal ini terjadi karena langkah-langkah pembelajaran pada model PQ4R memberikan kesempatan kepada siswa untuk melakukan pengulangan terhadap karangan yang akan dibaca sehingga informasi yang diperoleh siswa pada bahan bacaan akan diingat oleh siswa dalam jangka panjang. Hal ini sejalan dengan pendapat Linayaningsih (Linayaningsih, 2011) melalui tahapan dalam metode PQ4R, yaitu melalui pengulangan dan latihan, informasi yang diterima oleh siswa yang diterima oleh siswa dilanjukan ke ingatan jangka panjang. Informasi yang disimpan dalam ingatan jangka panjang bersifat lebih permanen, sehingga hal ini menguntungkan bagi siswa karena ingatan mereka mengenai informasi pelajaran yang mereka pelajari sebelumnya masih dapat mereka ingat. Selain itu, metode pembelajaran PQ4R memiliki prosedur yang memusatkan siswa pada pengorganisasian informasi yang bermakna dan melibatkan siswa dalam keterampilan bertanya serta memiliki kesempatan untuk mereview informasi yang diperoleh siswa.

Ketiga, pada indikator dapat menentukan ide utama dalam paragraf terdapat peningkatan sebesar 28\% di kategori sangat baik. Peningkatan ini dimungkinkan terjadi karena langkah reflect dan recite pada model $\mathrm{PQ} 4 \mathrm{R}$ menekankan kepada siswa untuk memahami informasi yang direpresentasikan dengan cara menghubungkan subtopik-subtopik di dalam karangan dengan dengan konsep-konsep atau prinsip-prinsip utama. Hal ini sejalan dengan temuan Rikmasari (Rikmasari \& Lestari, 2018) PQ4R memberikan kesempatan kepada siswa menemukan ide pokok atau gagasan utamanya dengan mandiri sehingga siswa lebih memahami isi bacaan yang telah dibacanya. Selain itu, metode PQ4R pada hakikatnya merupakan penimbul pertanyaan dan tanya jawab yang dapat mendorong pembaca teks melakukan pengolahan materi secara lebih luas dan mendalam (Yuliana \& Fajriah, 2013).

Keempat, pada indikator mampu menentukan amanat dalam karangan terjadi peningkatan di kategori baik sebesar $4 \%$ dan pada kategori baik sekali masih sebesar $14 \%$. Peningkatan kemamampuan menentukan amanat dalam karangan ini terjadi karena pada model pembelajaran PQ4R mengembangkan pemahaman konsep siswa. Kegiatan ini dilakukan cara sistematis, sehingga memungkinkan proses penyimpanan memori yang baik atau retensi yang baik. Hal ini sejalan dengan temuan Setiawati (Setiawati \& Corebima, 2017) strategi PQ4R merupakan suatu strategi yang membantu transfer penjabaran informasi baru dari memori jangka pendek menjadi memori jangka panjang dengan membuat sambungan antara informasi baru dengan informasi sebelumnya yang sudah diketahui. Selain itu pada langkah pemebelajaran recite siswa diminta untuk mengevaluasi hasil bacaan dan menjawab pertanyaan yang diajukan oleh siswa sendiri.

Kelima, pada indikator mampu membuat ringkasan pada karangan terjadi peningkatan sebesar 5\% dikategori baik dan 9\% dikategori baik sekali. Hal ini dimungkinkan karena pada langkah pembelajaran review pada model PQ4R siswa diwajibkan untuk membuat ringkasan dan menjelaskan hasil bacaan menggunakan bahasa siswa sendiri (Sarimanah, 2016). Selain itu pada 
langkah review siswa dapat membaca intisari dari ringkasan yang telah dibuat (Nindy Rahayu, 2017). Selain terjadi peningkatan hasil penelitian ini juga masih menunjukan sebagian besar siswa masih berada pada kategori buruk pada indikator mampu menentukan amanat karangan dan mampu membuat ringkasan karangan. Hal ini dikarenakan siswa masih mengalami kesulitan dalam mengingat kembali isi bacaan serta mengalami kesulitan dalam menyipulkan isi bacaan. Hal ini sejalan dengan temuan Tusfiana (Tusfiana \& Trynasari, 2020) bahwa peserta didik mengalami kesulitan dalam membentuk konsep dan mengembangkan kedalam unit-unit semantik, kesulitan dalam relasi semantik, kesulitan dalam mengingat kembali isi bacaan dan kesulitan dalam kemantapan arti dari suatu kata baru.

\section{Kesimpulan}

Berdasarkan hasil penelitian dan pembeahasan dapat disimpulkan terdapat perbedaan secara statistik kemampuan membaca pemahaman siswa sebelum dan sesudah mengikuti pembelajaran menggunakan model PQ4R. Hal ini dimungkinkan karena model pembelajaran PQ4R salah satu model pembelajaran yang menekankan keaktifan siswa dalam memahami isi bacaan. Langkah-langkah pembelajaran pada model PQ4R memberikan kesempatan kepada siswa untuk mengaktifkan kemampuan memori jangka panjang dengan pengelolaan informasi jangka pendek yang diperoleh siswa melalui pengulangan-pengulangan membaca. Dilain pihak, sebagian besar siswa masih mengalami kesulitan pada indikator menentukan amanat dalam karangan dan membuat ringkasan karangan. Hal ini diperlukan penelitian lebih lanjut untuk mengetahui bagaimana hal ini bisa terjadi dan upaya yang harus dilakukan untuk mengatsi hal tersebut.

\section{Daftar Pustaka}

Boliti, S. (2013). Peningkatan Kemampuan Membaca Pemahaman Siswa Kelas IV SDN 1 Lumbi-Lumbia Melalui Metode Latihan Terbimbing. Jurnal Kreatif Tadulako Online, 2(2), $12-23$.

Linayaningsih, F. (2011). Metode PQ4R (Preview, Question, Read, Reflect, Recite, Review) Untuk Meningkatkan Prestasi Belajar Pendidikan Kewarganegaraan. Najalah Ilmiah Informatika, 2(2), 75-86.

Mustofa, M. H., \& Rusdiana, D. (2016). Profil Kemampuan Pemecahan Masalah Siswa pada Pembelajaran Gerak Lurus. Jurnal Penelitian \& Pengembangan Pendidikan Fisika, 2(2), 15-22. https://doi.org/10.21009/1.02203

Nasution, N. H. (2018). Pengaruh Model Pembelajaran PQ4R Terhadap Hasil Belajar Siswa Kelas X SMA Materi Ekosistem. Proceeding of Biology Education, 1(1), 24-29. https://doi.org/10.21009/pbe.1-1.1

Nindy Rahayu, T. A. D. (2017). Pengaruh Penggunaan Metode PQ4R (Preview, Question, Read, Reflect, Recite, Refiew) Tehadap Hasil Belajar Ekonomi Siswa Kelas X Semester Genap SMA Negeri 1 Punggur. Promosi: Jurnal Program Studi Pendidikan Ekonomi, 5(2), 109-117.

Pramana, K. A. B., Lasmawan, I. W., \& Istri Ngurah Marhaeni. (2014). Pengaruh Penerapan Pembelajaran PQ4R Kontekstual Terhadap Hasil Belajar IPS dan Sikap Peduli Lingkungan Siswa Kelas V SD Gugus I Gianyar. E-Journal Program Pascasarjana Universitas Pendidikan Ganesha, 4(1), 1-10.

Rikmasari, R., \& Lestari, M. (2018). Metode Pembelajaran PQ4R Dalam Peningkatan Kemampuan Membaca Pemahaman Siswa Kelas V di Bekasi. JMIE (Journal of Madrasah Ibtidaiyah Education), 2(2), 265. https://doi.org/10.32934/jmie.v2i2.78 
Sarimanah, E. (2016). Efeectivenes Of PQ4R Metacognitive Strategy Based Reading Learning Models in Junior High School. IJLECR - International Journal of Language Education and Culture Review, 2(1), 74-81. https://doi.org/10.21009/IJLECR.021.08

Sartika, W., \& Effendi, M. S. (2019). Pengaruh Model Pembelajaran PQ4R (Preview, Question, Read, Reflect, Recite, and Review) terhadap Kemampuan Menganalisis Unsur Naskah Drama Siswa Kelas XI SMA Negeri 3 Lubuklinggau. Diksa: Pendidikan Bahasa Dan Sastra Indonesia, 5(2), 86-93. https://doi.org/10.33369/diksa.v5i2.9987

Setiawati, H., \& Corebima, A. D. (2017). The Corelation Between Concept Gaining And Retention In PQ4R, TPS, AND PQ4R-TPS Learning Strategies. Advances in Social Sciences Research Journal, 4(9), 22-28. https://doi.org/10.14738/assrj.49.3141

Slamet, S. T. . (2009). Kemampuan Membaca Pemahaman Mahasiswa. Paedagogia Jurnal Penelitian Pendidikan, 12(2), 118-129. https://doi.org/https://doi.org/10.20961/ paedagogia.v12i2.36029

Somadayo, S. (2016). Pengaruh Model Pembelajaran PQRST Terhadap Kemampuan Membaca Pemahaman Ditinjau dari Minat Baca. Edukasi, 13(1), 31-40. https://doi.org/10.33387/j.edu.v13i1.24

Tetu, F., Simpen, I. W., \& Sutama, P. (2019). Penerapan Strategi PQ4R Untuk Mengingkatkan Keterampilan Membaca Intensif Siswa Kelas V Menggunakan Media Teks Cerita rakyat Rongga Pada Sekolah Dasar Katolik Pau Ndoa Kota Komba Manggarai Timur. Linguistika: Buletin Ilmiah Program Magister Linguistik Universitas Udayana, 26(1), 54. https://doi.org/10.24843/ling.2019.v26.i01.p07

Tusfiana, I. A., \& Trynasari, D. (2020). Kesulitan Membaca Pemahaman Siswa SD. Proseding Konferensi Ilmiah Dasar.

Wangka, A., \& Usman, M. (2017). Penerapan Strategi Pembelajaran PQ4R (Preview, Question, Read, Reflect, Recite, dan Review) dalam Meningkatkan Prestasi Belajar PAI. Tarbawi: Jurnal Pendidikan Agama Islam, 1(1), 68-76. https://doi.org/10.26618/jtw.v1i1.359

Yuliana, I., \& Fajriah, N. (2013). Penerapan Metode PQ4R dalam Pembelajaran Matematika di Kelas VII SMP. EDU-MAT: Jurnal Pendidikan Matematika, 1(1), 1-10. https://doi.org/10.20527/edumat.v1i1.550 